brethren, and they, it is to be feared, have found it necessary to recede from the position they had taken up. No doubt this position may have from the position they had taken up. No doubt this position may have brethren, but, having once crossed the Rubicon, it was scarcely wise to brethren, but, having once crossed the Rubicon, it was scarcely wise to attempt to retrace their steps. The Yarmouth Mercury of November 28 th alluding to their action, says: "At any rate, it was to be expected that they would have guarded themselves against weakening the cause of their profession by unconditionally surrendering, which they practically did, at the delegates' meeting held last Friday night, and so create the im pression that they wanted toavail themselves of the benefits, should there be any, of the agitation which germinated at Yarmouth, etc., so that it would appear their concessions have hardly been taken in good part and their likely to put them in a worse plight than would have been the case had they shown more consistency and greater dignity. Our contemporary speaks about differences between Yarmouth and Gorleston. Very likely there are sueh, but it is diffcult to see how any local differences can make it right for the profession at Gorleston to endure what their brethren at Yarmouth have repudiated. Our contemporary concludes by saying: There is one thing 1 would point out, and that is, the medical profession are evidently bentiupon, sooner or later, if their connection is not severed. effecting some strictures upon the freedom so dear to the friendly societies.

If the "freedom so dear to the friendly societies" is the right to insist on the doctor attending to any member, no matter how wealthy, at the present club rate, and practically to ruin him by making all his private patients club members, it is not to be wondered the profession "are bent on, sooner or later," let us hope sooner, restricting the "liberty that is held so dear."

\section{IRISH WORKHOUSE REFORM.}

\section{By W. R. MACDERMOTT, M.B.}

Poyntz Pass, Newry.

IV.-The True Guardian.

In the reform we aim at we will, of course, find ourselves damped more by cynical agreement than direct opposition. An lrish medical officer once said to me: "All men are born masters and slaves; you would rid our people of one set of masters, and they would never rest until they found another set worse for themselves and for you." That was only a phase of the Frenchman's mind, who said, pointing to Christ on the Cress: "There, my son, is the fate of the reformer."

Human institutions, however, are only part of natura existence, and, as such, to be studied free of our notion of responsibility for them. Not that such responsibility is to be ignored. Reform in our Poor-law system must go on recognition in it of tendencies for evil counteracted by tendencies for good. In its inception it was devised in 1837 partly to save life and partly to avert from the governing element the scandal and danger of wholesale loss and insecurity of life in the mass. For its end a clumsy and cumbrous piece of Governmental machinery was called into existence expressly in accordance with the ideas of the then ruling element. All human experience tells as that every Governmental agency subordinates its professed object to itself, tends to become its own object. From the first our workhouse system subordinated the professed object of saving life to the condition of power in the governing element and that condition, that interest, has ever gone on developing at the expense of and under cover of the object. The personality of the element has changed, but the grasp and use of its power never. Our workhouses now are not really to relieve the poor, but to get rid of the residuum of labour unprofitable to the governing element, and that element further strives to make them subsidise the labour it needs, and lives on by means of outdoor relief and building labourers' cottages. This is the tendency for 'evil. Our object, the saving and protection of life, has had a long and unequal struggle against that tendency.

When the Poor Law made medical men its agents the struggle was unconsciously initiated. These men brought into the system ideas utterly at variance with those it rested and developed on. The ethics of their profession gave them an idea of the sanctity of human life which could not otherwise than influence them. Theirs might be the lot of fat and easy-going officials, or of servile employees bound to watch the nod of the parochial Jove; in the long run the mind of the profession in them would be bound to assert itself and ever more emphatically against the vicious mind of the system, its abuse of power under the cloak of charity.

We have the common fashion of disparaging our own body our faults are plainer to ourselves than others. But the graver faults of the medical officers are to be charged to the system. Its leading characteristic is contempt for life, and the mode of appointment of the officers devised in the interest, not of life but of the governing element and to gratify its petty vanity of power did not attempt the exclusion of the unfit, much less the selection of the fittest. Thus the body is, and always has been, under the influence of the evil system, but still its good genius.

It stands out in clear contrast. The system in the past used death to clear estates, now it uses it to clear away the unprofitable residuum of labour for employers. That action the local bodies accept with passive understanding. It is enough that they are not responsible for the law; they were not bound to be better than it ; it made life the object of their discretionary charity, and they accepted and acted on the principle. From the first, and always, they took up an attitude of passive irresponsibility for the workhouse deathrate; they would not look at, realise it; they went behind the responsibility of the law.

But the medical officer because he was a medical man was better than the law; its principle could never be his. From the first he tried to improve the workhouses. Practically his task was to prevent things in obedience to the spirit of the system getting much worse. The routine of the thing came to be that he was just able, acting through the Local Government Board, to stem criminal negligence. His doing a little more depended on whether a humane spirit or the typical rural economist was uppermost at his Board. His was the one mind in connection with the workhouses with any idea whatever of improvement, and that they are not much worse is the result of the continuous struggle on his part against inert or hostile elements. But the guardian paid the bill. In reality the medical officer paid, as did no individual ratepayer. The standard of attendance on the pauper has been raised by him at the expense of time and labour to himself; every improvement taxed him first and most; but the ratepayer had little claim on him. The Irish poor-rate is $£ \mathbf{r}, 000,000$, of which about $£ 8,000$ goes as half his salary to the workhouse medical officer. The great mass of work he does is met, not by direct payment, but under the often illusory pretence that private practice goes with the office. He would be cheaply bribed if he was loyal to the system. We may thus see him as the one element working for good in that system, the true guardian of the poor, under narrow means and discouraging circumstances. Now reform only means whether his mind, the mind of the profession, is to prevail or not over the savage governmental tradition, which puts life wholesale at the mercy of discretionary charity, it matters not in whom vested; the vioious idea cannot but vitiate the minds which entertain it; act on it. Never till his mind prevails will the historical death roll of the workhouse system be closed. He may think that all he can do is to introduce a little decent regard for life into the system, that the real remedy is beyond him; is for the old dreary round of Irish agitation and political warfare. But even that statement coming from him is for those it concerns. So long as a quarter of the Irish labourers die in the woikhouses under conditions their medical officers themselves condemn, so long as the horrible sense of insecurity of life oppresses the labouring population, so long will political stability be impossible in Treland.

From the first, however, the medical officer committed himself altogether against the false charity system: he could not keep to the mind of the profession otherwise. His individual action long preceded the action of this JouRnaL, and all we can do here now is to give his action the sharpness of definition, to formulate it, to strive to make it the conscious settled policy of the collective body, and not voiceless at issue with that of the State.

\section{THE ELECTION OF DIRECT REPRESENTATIVES AND THE MIDWIVES QUESTION.}

WE have received the further following letter on this subject:

SiR,-In view of Lord Kinnaird's letter which appeared in the British Medical. Jodral of November 28th, I need only add in reply to Dr. McCook Weir's reiterated statement, that the only forceps carried : by our'nurses are the ordinary: dressing forceps for surgical work; and that the 2,280 confinement 
cases to which he refers were attended by our nurses in their capacity of monthly nurses, and under doctors or certificated midwives:-I am, etc.

\section{E. Selfe Leonarb,}

Hon. Sec. of the Biblewomen and Nurses Mission. Adelphi Terrace, W.C., Dec. 8th.

\section{JENNER MEMORIAL MEDAL FUND.}

WE are requested by the Hon. Treasurer of the Epidemiological Society to publish the second list of subscribers to the above fund, and to state that the subscription list will close at the end of the year. Subscriptions (limited to I guinea) may be sent te the Hon. Treasurer, Dr. Sweeting, 6 , Hereford Mansions, Bayswater, W.

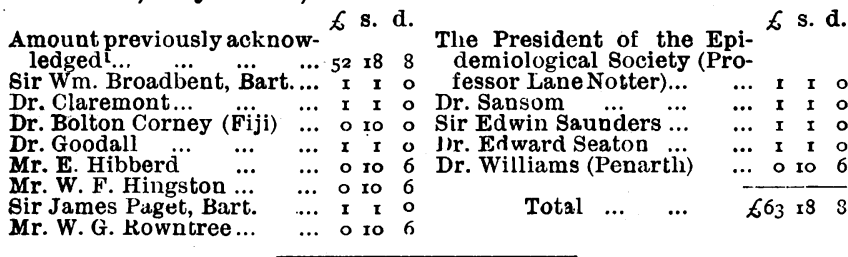

\section{LITERARY NOTES.}

Princess Christian has signified to Mr. Edward Arnold her special permission for the dedication tu herself of $A$ T extbook of Nursing, edited by Mr. W. Radford, of the Poplar Hospital, with an introduction by Sir Dyce Duckworth. Her Royal Highness has also been pleased to accept a copy of the work from Sir Dyce Duckworth.

The Casa Editrice Francesco Vallardi, of Rome, Naples, Florence, etc., has just published a volume in which are collected all the addresses, papers, and notes of Professor Maragliano, of Genoa, from August, I895, to June Ioth, 1896, relative to the method of serum treatment of tuberculosis, with which his name is associated. This book contains the whole history of the method and the results of the author's labours in the laboratory, and of his therapeutic experiments and clinical observations on the subject during the last four years.

Dr. Ridley Bailey (Bilston) writes :

In my address on Medical Education and Examinations (BRIrisH MEDicaL JOURNAL of November $2 x$ th, $1896, p$. 156x) I quoted the following from Matthew Arnold:

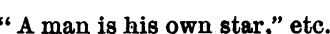

"A man is his own star," etc.

My friend, Dr. Herbert Smith, of Ealing, writes to me to point out that these words are really taken from John Fletcher (1576-1625), On an Honest $M a n^{\prime} 8$ Fortune.

The lines run thus:

Man is his own star and the soul that can

Render an honest and a perfect man

Commands all light, all influence, all fate

Nothing to him comes early or too late.

Our acts our angels are, or good or ill,

W.S. also points out that the lines are from the Epilogue to Beaumont and Fletcher's Honest Man's Fortune, which he thinks are "familiar to most of us, probably from being preprefixed by Emerson to his essay on 'Belf-Reliance.'"

The New York Journal of Nervous and Mental Disease is the leading organ of neurology in the United States, and is favourably known to all cultivators of that special field of medicine throughout the world. The following new arrangement of the staff has been made for the coming year:-Editors: Dr. Chas. L. Dana, Dr. F. X..Dercum, Dr. Philip Coombs Knapp, Dr. Chas. K. Mills, Dr. Jas. J. Putnam, Dr. B. Sachs, Dr. M. Allen Starr. Associate Editors: Dr. Philip Meirowitz, Dr. Wm. G. Spiller. Managing Editor: Dr. Chas. Henry Brown, 25, West 45th Street, New York, to whom all editorial and business communications should be sent.

The first number of the Russian Review of Psychicatry, Neurology, and Experimental Psychology, a new Rissian periodical, the character and scope of which are indicatied by the tatle, will appear on Jahuary 2oth; 1897 . It is to be a

1 British Medical Jodrad, Öctóber zrâd, 1896. monthly publication under the editorship of Dr. W. Bechterew Professor and Director of the Clinic of Mental and Nervous Diseases at St. Petersburg.

It is announced that the Union Médrcale, one of the oldest medical journals of France, has ceased to appear. It was founded and edited for about fifty years by the late Dr. G. Richelot, and since his death it has been conducted by his son, M. L. G. Richelot, Professor agrégé of the Paris Faculty, and Surgeon to the Hôpital Saint Louis. M. Richelot finds that the increasing pressure of other engagements makes it impossible for him to give sufficient attention to the work of editorship. He therefore invites his readers to transfer their support to the Bulletin Médical.

In the BRITISH MiEdical JouRnal of November 28th reference was made by Mr. George Pernet in his Historical Notes on Splenectomy to an operation said to have been performed by an Italian in the sixteenth century. As this, if authentic, is the earliest splenectomy on record, it may be interesting to quote the original report of it as given by Fioravanti. Lenardo Fioravanti was a native of Bologna, and seems to have been a skilful operator with a considerable element of quackery in his mental composition, such as is found in several of the early pioneers of surgery. He was certainly a boastful person, as may be gathered from his statement that he did not envy "those who are dead nor the living, nor even those who are to come, since I have reduced surgery to such a condition that it is impossible for it to advance further." $\mathrm{He}$ is said to have removed the uterus and bladder from a woman in Naples who had been maltreated by a midwife. The splenectomy which has made the name of Fioravanti, famous (among Dryasdusts) was performed at Palermo in 1549; on his own showing he was not the operator, but with a genius for advertising which would do credit to the greatest practitioners of that fine art in our own day, he managed to get all the credit and doubtless most of the profit of it. Fioravanti's account is given in his Tesoro della Vita Humana, published at Venice in 1560 . The following is a translation of it :

Cure of a Woman from whom I removed the Spleen. - This very year in the month of April aforesaid I was called in to a Greek woman who lived near the garden of the Marquis di Terranuova, and who was the wife of Captain Marco, a Greek, who died afterwards in the year $5 \mathrm{r}$ in the war of Africa; and this woman was named Marulla, a young woman of the age of 24 years, in whom a very great oppilation of the spleen took place, and it grew so much in the body that it could not contain more. and it caused both legs to be most grievously ulcerated, so that the poor thing could no longer live, and being visited by divers doctors she was told that if she wished to be cured it was necessary to remove the spleen from her body forth; so that the poor thing, who had been the most beautiful woman forth; so that the poor thing, who had been the most beautiful woman of that city and a great favourite, made up her mind to die or get well, and began to entreat the captain her husband that he should find someone who would remove this spleen. and so instantly she begged him that the poor gentleman began to seek for a doctor to do this thing, and so seeking found me. He came to my house and took me to his house to see this woman and I saw her, reasoned with her, and comforted her as best I could: and she asked me if 1 had sufficient courage to remove her spleen, and I answered her cheerfully, Yes, although had never removed one before, but afterwards in nother, as I will describe in the proper place; so I promised her to do his thing ; and this promise she every day importuned me to fulfil; and I, to say sooth, albeit I had promised, did not wish to do it for fear of making a mess of it : but notwithstanding this I sent for a certain aged man of the Kingdom of Naples; belonging to a town which is called Palo, which old man was named Andriano Zaccarello, who in that town cut for stone, extracted cataracts and such like, and was very skilful in that business, and the said old man came at once to my house, and I said to him, Dear Messer Andriano, a quaint idea has come to the wife of the Greek Captain Marco to wish to have her spleen removed, I should like to know from jou if that is a thing that can be done without danger? The old man answered me, Yes, sir, it can be done. because it is a thing which has been done several times in my life. I replied, Have you nerve enough to do this? He replied that in conjunction with me he would do went to find the woman, and arranged with her and her husband; and having done so I went to the police authorities to report her dead, as is the custom ; and having got permission, we went one morning to the house of the said woman. And the good old man took a razor and cut the woman's body over the spleen, and having cut the spleen it jumped forth from the body; we proceeded to separate it from the reticella (? pedicle), and we got it all out and stitched up the body. leaving only a small venthole, and I dressed it with compound hypericum oil and powder of incense, mastic, myrrh and sarcacola, and I ordered her a draught of water boiled with common honey, as a consolidating substance, hyperioum, betonica, and carduus sanctus: and every day I made her take a dose of theriaca ; and thus I continued helping her in such wise that the poor thing was healed in twenty-four days and she went to mass at our Ltdy of Miracles near the custom house and was well and sound; and the spleen which was taken out of her body weighed thirty-two ounces. It was taken to the gallery of the merchant and there remained three days so that all the town saw it: and the glory 